\title{
Ethnic Conversions: Family, Community, Women, and Kinwork ${ }^{1}$

\author{
Mary E. Kelly \\ Central Missouri State University
}

\begin{abstract}
According to the straight-line theory of assimilation, ethnic groups by the third or fourth generation should be entirely assimilated into mainstream society and should identify themselves as "Americans." Yet there has been a resurgence of ethnicity among white ethnics in the United Sates that has led to a renewed interest in particular ethnic groups and their cultures. Third- and fourthgeneration European Americans claim an ethnic identity even though their ties to their ancestral homeland may be tenuous. Lithuanian Americans in Kansas City, Kansas, in the 1950s, 1960s and 1970s would seem to provide support for the straight-line theory of assimilation, yet since the 1980s they have reconstituted themselves through the Lithuanians of America organization and are experiencing a renewal of their ethnic identity. The Lithuanian American community in Seattle, Washington, also experienced ebbs and flows in the activism and unity of its members. The community was active at the turn of the twentieth century, next revitalized by Lithuanian emigres following World War II, and then became active again in the late 1970s after a decade of inaction. Members of the two groups were given questionnaires in the early 1990s to address the ethnic identity fluctuations as well as the role of non-ethnics in the organizations. One of the more exciting findings from the surveys and from participant observation was the extensive role of "ethnic converts" in the Kansas City organization, and their lesser (but still significant) role in the Seattle Lithuanian-American community.
\end{abstract}

Ethnic Studies Review Vol. 19, No. 1 (February 1996): 81-100. 


\section{The Persistence of Ethnic Identity}

There is no doubt that ethnic revivalism is a force in American society. ${ }^{2}$ However, though it may be true that individuals revive their ethnic identity, the meanings behind the revivals vary. By "ethnic identity," I refer to a group's or individual's cultural construction of their ethnic past which is grounded in an historical context but which also responds to changes in the lives of both groups and individuals. ${ }^{3}$ Ethnics are not returning to the ways of their ancestors but are instead choosing cultural symbols (such as folk dancing, folk singing, ethnic festivals, and consumption of ethnic foods) to incorporate into their identities. ${ }^{4}$ Ethnic Americans feel free to put on or take off their identities depending on the circumstances they find themselves in, and construct ethnic identities and cultures as a way of linking themselves with society. ${ }^{5}$ People with multiple heritages pick and choose the ones they identify with, "feeling" more like one ethnicity when they are performing traditional dances, for example, or when they are associating with friends of that ethnicity. The constructed nature of ethnic identity is even more readily apparent when individuals engage in ethnic "switching" or fully convert to another ethnic identity. ${ }^{6}$ I argue that ethnic groups and individuals actively construct an ethnic identity through the creation of ethnic symbols, boundaries, communities, and culture that change depending on both group and individual circumstances.

The construction of ethnic identity, ethnic boundaries, and community can be seen through an analysis of the maintenance and/or creation of Lithuanian-American ethnic identity by people of Lithuanian descent, non-Lithuanians, and Lithuanian-American communities and organizations. Analysis of this small American ethnic group allows one to observe the strategies adopted by groups when their numbers dwindle due to assimilation and dispersal from a central location. It is logical to predict that ethnic boundaries will become more permeable when there is fear of ethnic communities being lost altogether but that they will be more rigid during times of stability for the group. Ethnic groups with more flexible boundaries would be more likely to welcome ethnic converts into their midst. Through comparing two different Lithuanian-American organizations, the LOA and Bendruomene, it is possible to compare the ethnic boundaries maintained by the groups and to see the role that women, families, friendship networks, and organizations play in encouraging "ethnic converts." Because the two organizations have had different policies about accepting non-Lithuanians into their groups, the comparison makes clearer the necessary antecedents for the acceptance of ethnic converts. I explore how ethnic identity is transmitted, usually through women, and show how even those without an ethnic ancestry can adopt an ethnic identity. 


\section{Women, Kinwork, and Family Structures}

Families and kinship networks play a key role in maintaining and strengthening ethnic ties and identity because they keep alive ethnic traditions and rituals that would otherwise be lost during periods of low ethnic awareness. Ethnic structures, such as families, churches, schools, and social organizations preserve ethnic identity through multiple generations and dispersal into the suburbs. For instance, family participation in powwows and other symbolic and instrumental interaction confirm Native American ethnic identities in urban and suburban communities, far from reservation communities. ${ }^{7}$ Women often act as ethnic architects within family structures; they play a central role in symbolic ethnicity, because it is usually women who cook the traditional foods and socialize their children to have a particular ethnic identity. ${ }^{8}$ For example, Mexican-American women have been instrumental in keeping families together and transmitting culture by cooking traditional foods. ${ }^{9}$

Families (especially their female members) actively create symbols of ethnic identity; in fact, family history and culture are used as representations of ethnicity. ${ }^{10}$ These symbols, such as the celebration of holidays, become a means of retaining old traditions and practices, and define the family in an ethnic context. Language is another important component of ethnic identity transmission. In a 1983 study of Lithuanian scouts, Van Reenan found that the women played an important role in determining ethnic identification because they were the ones who passed on ethnic traditions and the Lithuanian language. ${ }^{11}$ When mothers did not teach Lithuanian traditions in the household, the traditions were often lost.

Women often perform the role of ethnic transmitter even when they are non-ethnics themselves by transmitting their partner's ethnicity to children. Thus, kinwork becomes an extension of the more widely documented "invisible labor" of women, and women become a major force in ethnic renewals. Women are expected to maintain family and ethnic identities through their kinwork and are responsible for organizing the cross-household gatherings that are necessary for the transmission of ethnic behaviors and beliefs. ${ }^{12}$ In fact, according to di Leonardo's study of Italian American families, kinship ties diminish or die without an adult woman present in the household, and often women know more about their husband's family ties and background than the men themselves do. ${ }^{13}$ The fact that the work of ethnic identity transmission is sometimes even done by non-ethnic women supports the importance of women in transmitting ethnic identity. 


\section{Ethnic Conversions}

A brief review of the general literature on conversion sheds some light on the processes behind ethnic conversions. ${ }^{14}$ Research on conversions usually centers on religious conversions, however, there is nothing particularly "religious" about the conversion process. ${ }^{15}$ Conversion occurs any time a group encourages identity change among its members. Although some researchers assume that conversions create a radical shift in the convert's world view, not all conversions are of such an extreme nature. ${ }^{16}$ Suchman, for example, argues that most conversions do not have such life-transforming consequences and that "everyday conversions" are more likely to provide a sense of group solidarity than a drastic reorientation of personal ideologies. ${ }^{17}$ In my analysis of ethnic converts, I focus on conversion as a means of providing a sense of group solidarity. To that end, I concentrate on the everyday conversions associated with organizational affiliation and allegiance rather than changes in belief systems.

Religious exogamy is one reason for religious switching, a spouse's desire to convert to their partner's religion. Sometimes it is seen as essential for children in a family that both parents be of the same religion, and therefore, if the parents are of different religions, one of them converts--usually the mother. ${ }^{18}$ At least one study indicates that ethnic conversions are done for similar reasons; one ancestry is privileged over the other in order to make the transmission of ethnic identity to the children easier. Often it is the father's ethnic ancestry that is transmitted, usually due to his surname (and therefore ethnic heritage) being representative of the entire family. ${ }^{19}$ For example, among Native Americans, "some non-Indians who marry Indians become incorporated into the tribal cultures of their spouses." 20 Usually it is wives who are converted.

Another argument that is made about religious conversion is that association with other members of a religion are what leads one to convert. Membership in an organization is of importance because "it is through becoming committed to an organization that an individual becomes converted to the organization's perspective." 21 Friendship networks can also influence an individual's religious or ethnic identity. In a review article examining ten case studies of religious conversions, researchers found that the factors most crucial to the conversion process were the "formation of affective bonds with group members" and "intensive interaction with group members." 22 In one particularly compelling case, Stephen reports that a Chinese-Laotian girl identified herself as a "Chinese Caucasian" when associating with her mostly Caucasian friends. ${ }^{23}$ Even when she was not with her friends, however, she reported that her primary identity was as a "Laotian-Chinese Caucasian." Women, through marriage and other familial relationships, of- 
ten draw non-ethnics into family networks and thus into the ethnic community. Non-ethnics also become part of the ethnic community through cultural and political participation, such as taking part in folk-dancing groups, folk-singing ensembles, and ethnic festivals, as well as supporting independence movements. They become "converts" when they adopt a new, nonancestral ethnic identity and often extend their participation to other activities involving the ethnic community and its ancestral homeland, such as taking language classes and maintaining connections with people and organizations in the adopted homeland. What is fascinating, because it highlights the constructed nature of ethnic identity, are the processes through which people without Lithuanian ancestry come to identify very strongly with Lithuanian Americans and Lithuania, and thus "become" Lithuanian American. The Lithuanian-American converts in my study, for instance, became actively involved in Lithuanian-American organizations through marrying into Lithuanian-American families and/ or joining the organizations directly, usually through their folk-dancing groups. My analysis of Lithuanian-American converts focuses primarily on the role of families, women, and Lithuanian-American organizations in the ethnic conversion process.

\section{Lithuanian-American Converts}

As in much religious conversion, marriage serves as a common path to Lithuanian ethnic conversion. 24 The Lithuanian-American converts I studied were most likely to adopt the goals, ideology, and rituals of the families they have married into or those of the Lithuanian-American organizations they are members of. Not surprisingly, the marriage itself was of significant importance to the respondents. What was more important, however, was the birth of children and the perceived necessity to instruct them in their ethnic background. The family seemed to have the most effect in transforming one's ethnic identity when the convert had a weak ethnic identity to begin with and/or when the family they married into had a strong ethnic identity bolstered by ethnic activities. The only converts I was able to identify in Bendruomene, for example, were all married to people of Lithuanian descent. (While only two nonethnics responded to my survey, I identified several others through my participant observation and analysis of their ethnic conversions are included in this article as well). However, some of the converts in the LOA did not have familial ties, but instead converted through their involvement in the LOA and/or the Aidas dance group. 25

The Kansas City LOA has a much higher percentage of nonLithuanian membership as well as ethnic converts than does Seattle's Bendruomenè. LOA also has had leaders who are non-Lithuanian, while the Seattle Lithuanian-American organization has not. In fact, recent LOA election of officers is a good example of the acceptance of non- 
Lithuanians in the community. Since the 1996 election, three out of the four LOA officers, including the president, are nonLithuanians. ${ }^{26}$ Two of the officers are married to Lithuanian Americans, but the new president has no such affiliation. In addition, one of the eight remaining board members is non-Lithuanian, but is married to a Lithuanian American. Non-Lithuanians have been recognized as a vital part of the LOA since its inception. For example, in 1981, the (non-Lithuanian) editor of the Varpas thanked non-Lithuanians for their help during the 1981 festivalas:

Non-Lithuanian Ken Berkin worked beer and drinks for many hours and Ken brought several non-Lithuanian friends who worked various shifts throughout the day, Jim Murray another non-Lithuanian, friend of Don Z., worked [all but] four hours in the drink booths. These and many other non-Lithuanians (about 15) worked without pay and we owe them a great debt of thanks. ${ }^{27}$

In Seattle, all current Bendruomenè officers and board members are of Lithuanian-American ancestry. Non-Lithuanians are sometimes, but rarely, mentioned in the Tulpe Times, and even then only fairly recently.

Despite the differences between these two communities, both do have ethnic converts and in both communities these converts are widely accepted by the group members as well as outsiders. However, Lithuanian-American converts appear to be accepted more readily in the LOA than in Bendruomene. In the Lithuanian-American communities in Seattle and Kansas City, I defined as ethnic converts nonLithuanian-American members who are involved in Lithuanian folk dancing or singing groups, are leaders of any Lithuanian-American organizations, represent Lithuanian Americans in other pan-ethnic organizations, or actively make an effort to inform others outside the Lithuanian-American communities about Lithuanian history, culture, or politics.

Sixty LOA respondents (out of 163) without Lithuanian ancestry responded to my surveys, while only two Bendruomene members (out of forty-seven) of non-Lithuanian ancestry responded. There are two likely reasons for the discrepancy in the percentage of non-Lithuanians who responded to the questionnaires. One is that I was able to mail out the questionnaires only once to Bendruomene, and in general did not receive as high of a response rate. A second, and more theoretically interesting explanation, is that the LOA group has much more permeable ethnic boundaries. Barth discusses the notion of an ethnic boundary dividing populations and outlines the conditions under which individuals can "migrate" across boundaries, thus changing their ethnicity. 28 These ethnic boundaries are determined by social interaction, that is to say, both by self-ascription and ascription by others. One must also act out the proper, culturally prescribed roles to be accepted. ${ }^{29}$ Thus it is 
necessary both for the converts to define themselves as "Lithuanian American" and for the group members to accept them as such.

In Bendruomene, for example, it is both less likely for nonLithuanians to define themselves as Lithuanian-American converts and less likely for Lithuanian Americans to accept non-Lithuanians as full members of the organization. Unlike the LOA, the Seattle LithuanianAmerican organization is heavily influenced by Lithuanian-American émigrés, who often have stricter definitions of the qualities necessary for an "authentic" Lithuanian American than ethnic Lithuanian Americans do. One Bendruomenè member (F 3G ethnic), for example, believes that the more rigid boundaries of émigré groups is due to their strong political attachment to Lithuania as refugees:

So this became a national purpose for Lithuanian communities all over the country after World War II, to "never forget" that Lithuania was illegally occupied. 30

Another Bendruomenè member (M 1G émigré) agrees that for the Seattle Lithuanian-American community, "the only glue really was this 'Save Lithuania' thing." ${ }^{11}$ Irena Blekys (1 G émigré) also believes that LithuanianAmerican émigrés have more restrictive ideas about being Lithuanian American:

We always felt (we as in World War II refugees) that "we" are Lithuanians. The other ones [ethnic Lithuanian Americans] when we came over didn't speak Lithuanian, or they have so many Americanisms ... And I think that in many ways we tended to keep them out and made them feel like they weren't good Lithuanians. 32

Bendruomenè, therefore, due to its larger concentration of émigrés, has less permeable ethnic boundaries than the LOA does.

Non-Lithuanians in the LOA, for instance, are welcomed without hesitation, while non-Lithuanians in Bendruomene are required to demonstrate their "Lithuanianess." Therefore, non-Lithuanian Bendruomene members are less likely to identify themselves as Lithuanian, and less likely to feel themselves to be "official" members in the group. Instead, they consider themselves auxiliary members. This variance is evidenced not only by their greater response to the surveys, but also by their strong leadership roles in the LOA. The leader of Aidas, for example, is a nonLithuanian married to a Lithuanian American, and there is also a nonLithuanian who, with her spouse of Lithuanian ancestry, regularly represented the Lithuanian-American community through her leadership role in the Kansas City Ethnic Commission. 
The majority of the non-Lithuanians were more than three generations removed from their own ancestry. Only six of the respondents reported that they were third or second generation. Among the Kansas City population with Lithuanian ancestry, almost a third were first or second generation and twenty-two percent were third generation. Only seven and a half percent reported that they were fourth generation, while nearly four percent were of mixed generations. None of the Bendruomenè members reported ancestry further removed than third generation. This helps to support the theory that those with tenuous ties to their own ancestry are more likely to adopt another, or at least to become more involved with the activities of another ethnic group. Of those respondents, I classified twelve LOA members as Lithuanian converts, and I considered both of the non-Lithuanian Bendruomene members to be converts and identified one other Bendruomene I interviewed, but who did not complete a survey, as a Lithuanian convert. (Other ethnic converts were mentioned in aBendruomenè newsletter, and referred to as "honorary Lithuanians," but I have little additional information about them.) Although fifteen respondents is a small percentage of the population studied, I believe it can still prove useful to try and trace how they constructed their new identities and why, and thus gain some insight into the ethnic conversion process.

I expected to find fewer ethnic converts in the Seattle LithuanianAmerican group because it is dominated by Lithuanian émigrés who are more likely to have rigid definitions of Lithuanianess than their ethnic Lithuanian-American counterparts, and, in fact, there were fewer. Although several of the respondents from the Seattle group reported less acceptance of non-Lithuanians and even of people of Lithuanian ancestry who married non-Lithuanians in the past, they also believed that tolerance was increasing for such members. They felt that they needed all the help they could get in order to maintain and even expand their outreach programs in the local community as well as their philanthropic efforts in Lithuania. From my interactions with group members, it became clear that when non-Lithuanian members were welcomed it was because the small size of the Lithuanian-American community deemed it necessary. These few non-Lithuanians, however, were not treated as Lithuanian-American converts. Instead, their role was seen as one of helping Lithuanian-American causes, either in preserving LithuanianAmerican culture or assisting Lithuania in achieving independence.

Although Seattle Lithuanian Americans are becoming more accepting, their ethnic boundaries are still quite rigid in comparison to the Kansas City group because émigrés tend to have more narrow ideas about what is necessary to be considered "Lithuanian American." Not only is there a smaller percentage of non-Lithuanians in the Seattle Lithuanian-American community than in the Kansas City one, but they are not found in leadership positions. In addition, non-Lithuanians are 
often included into the Lithuanian-American group through formal rituals in which they are named "honorary Lithuanians." Apparently there was a perceived need to ritually transform individuals so that they could penetrate the denser ethnic boundaries of the Seattle organization. According to an article in the Tulpe Times, the "certificates of Honorary Lithuanian Citizenship" were:

awarded in fun to well-deserving individuals who have contributed much deliberate effort and enthusiasm to the promulgation of Lithuanian activities in Seattle. The unsuspecting recipients were required to pass an "oral examination" prior to being awarded a new name along with their honorary status. ${ }^{33}$

No such rituals exist in the LOA; in fact it is rarely noted who is and who is not of Lithuanian ancestry. For example, in my own research of the LOA, I was surprised several times to find that members who I had assumed were of Lithuanian ancestry were not.

\section{Continuum of Conversion}

At the same time that there were variations in the extent to which non-Lithuanians were welcomed into Lithuanian-American organizations, there was also variation in the extent to which the Lithuanian converts regarded themselves as such. Some of the respondents made a point of indicating that they thought they were every bit as Lithuanian as those with Lithuanian ancestry. Constance wrote:

I feel I am truly Lithuanian although I am only by marriage. I feel you do not have to speak Lithuanian to be Lithuanian. In fact, all you really need is the desire of the heart. My involvement with the Lithuanian Freedom Movement has long surpassed a casual involvement of some 12 years of awareness on my part. The trip [to Lithuania] only intensified all of these feelings and showed me in reality what I had hoped for, a beautiful country with beautiful people.

Wayne has been so involved in the group that he sees himself as an adopted Lithuanian:

I'm an adopted Lithuanian, I really feel that way .... I'm proud of the people, proud of the Lithuanian costume I got there [in Lithuania]. 
$\mathrm{He}$ is not the only one who sees himself that way, however; another respondent wrote that "you couldn't ask for someone more Lithuanian [than Wayne]."34

Others, however, were equally clear that they felt they were not "real" Lithuanians. Mike, for example, wrote, "I'm just a 'fake' or 'pseudo' Lithuanian-American." Most responses fell somewhere in between, such as Darrell's:

I am not Lithuanian-American officially, but I found out you don't have to be. There are appealing aspects to being involved with this community that go beyond ethnicity (e.g. craftwork, art, respect for nature, bravery, etc.).

In addition, Lisa, who is adopted, wrote:

... I don't know what my actual ethnic identity is and I intend to find out. I would very much like to find out that my ethnic identity is Lithuanian, because I would be honored to be one of the hard working and kind Lithuanians.

In her case, she has chosen to identify with Lithuanians even though her adopted parents are not of Lithuanian descent. Through her own activities with the LOA, she has also drawn in her adoptive parents, who have volunteered their time for various fund-raising activities.

\section{The Role of the Family in Ethnic Conversion}

Ethnic conversion is partly a function of trying to maintain a consistent identity for all members of the household, parents and children alike. Most of the ethnic converts who are parents (nine have children) believe it to be very important to pass an ethnic heritage on to their children. Eight of them reported that they taught their children their ethnic heritage; the one who did not wrote that he simply did not know enough about his background in order to do so. Because the parents thought it important to explore their families' roots, they acted as ethnic transmitters to their children. For example, Kevin, who does not identify with his own ethnic background, wrote that his children are "taught Lithuanian identity, even though they are only $1 / 8$ Lithuanian because of our involvement."

There is also evidence of a "reverse cultural transmission" when parents become more ethnic because of having children and teaching them family history and passing on family traditions. ${ }^{35}$ In some cases 
the traditions did not even seem important to them until they had children to pass them on to. Jack Thompson, for example, wrote that teaching his children about their ethnic heritage "has helped me to understand the world better, to be aware of world conflict and cultures. Also [it] has helped form my identity."

His own identity was strengthened in his transmission of that identity to his children.

In addition, children can directly get their parents involved in ethnic culture. For instance, my parents did not become involved with Lithuanian-American activities until after I had joined and begun performing with Aidas when I was fifteen in 1981. Other adult relatives of mine reported that their "crazy niece" had gotten them involved in searching for their Lithuanian heritage.

Some of the respondents to my questionnaires traveled to Lithuania primarily because of the family ties the trip evoked. Kevin Parker, for example, wrote that "[travel to Lithuanian was a] chance to visit my wife's homeland and my adopted homeland." Another convert wrote:

I wanted to visit the country from which my husband's parents immigrated, to get to know the people and to dance with them, and to share cultural ideas. I felt that this would help my children to more fully appreciate their heritage. 36

They believed it was important to become involved with their spouse's family ties and to teach their children about their heritage. For them, the trip to Lithuania was a chance to experience more deeply their chosen ethnic identity.

\section{The Gendered Nature of Ethnic Conversion}

In a study of conversion to modern Orthodox Judaism, Davidman and Greil found that men and women chose to convert for different reasons. ${ }^{37}$ Men were more likely to be active seekers and to be interested in abstract theological issues while women were more likely to convert through personal contacts, and they emphasized family and personal relationships as reasons for their conversions. Again, we see the importance of family in conversion processes, particularly for women. Often the women felt it to be their responsibility to convert to their husband's religion because it was their responsibility to maintain the traditions of the household. 38

It seemed to be more important to the women to transmit a cultural identity to their children that corresponded to their surname, and 
hence with their father's ancestral background. As respondent Constance expressed it:

Long ago I felt if I carried the name of "Samalavičius" I should be able to speak intelligently about the origin and know the roots of the family.

She thought that her children needed to be taught about the history of the name they carried. She added that teaching the children their ethnic heritage was important because "it is imperative that children understand what has made up the personalities of their families."Sandy apparently agrees, because she wrote, "Since I married a Lithuanian, I have been instrumental in teaching [my children] their Lithuanian heritage."

Sometimes women become so interested in their spouse's Lithuanian heritage that they become more involved in Lithuanian activities than their husbands. In the Lithuanian-American community in Kansas, one of the primary leaders of the group is a woman with no Lithuanian ancestry, yet she is more active than her Lithuanian-American husband. For instance, she is learning Lithuanian--something her husband has never chosen to do. Likewise, the leader of Aidas is non-Lithuanian, yet she is learning traditional Lithuanian folk dances and also is taking Lithuanian language classes. Again, her husband has expressed no interest in learning Lithuanian. Sandy wrote of her own ethnic identity:

\section{I think of myself as American and sometimes as Lithuanian American and Irish American. I feel more Lithuanian than Irish.}

Constance also feels a strong identification with her husband's ancestry:
I consider myself as much or more a Lithuanian than most Lithuanians I know, mostly because I chose to be, therefore, dedicating my efforts without guilt or to please anyone else. My country is certainly [the] United States, but my heritage is considered to be Lithuanian.

Other examples include a couple in the Seattle group. The man is an ethnic Lithuanian and his spouse is not, yet Anne is the one who got them involved in the Lithuanian-American community through her involvement in the folk-dancing group. She is also learning Lithuanian, although her husband is not. 


\section{Ethnic Conversions through Nonfamiliar Routes}

Although most of the non-Lithuanians who were involved in Lithuanian-American organizations and activities with whom I spoke or who answered questionnaires were connected to people of Lithuanian ancestry by marital ties, there were others who became involved in the organizations through cultural (primarily folk-dancing) groups or because of their political activism on the behalf of Lithuanian independence. In essence, their route to ethnic conversion is through formal organizations rather than families. Although for many it is entirely understandable when the spouses (or significant others) of Lithuanian Americans become deeply involved in the Lithuanian-American community, it is more of a mystery why those without such ties become highly active. Such involvement pushes at the boundaries of ethnic construction processes.

These nonfamiliar ethnic converts indicated their involvement in formal organizations played a key role in their identification with Lithuania. For instance, one respondent initially became interested in Lithuania through his wife of Lithuanian descent, but also notes that they probably would not have expressed her heritage or taught it to their children if it hadn't been for the formation of the LOA. ${ }^{39}$ An example of the ethnic conversion through involvement in cultural organizations is the experience of Mike, a man of Norwegian descent. He initially became involved with the Lithuanian-American community in Kansas when he joined their folk group Aidas simply because he enjoyed folk dancing and was eager to try new styles of folk dancing. His interest in Lithuania became heightened as he found out more about it from the other dance members.

Anne, for example, a member of the Seattle Lithuanian-American organization, has become very interested in Lithuanian folk weaving and was partly responsible for an exhibit on Lithuanian weaving at the University of Washington and is learning Lithuanian weaving herself. She became interested in Lithuania first through its folk art, and then began to learn more about Lithuania, including its language. Her entrance into the group was first through interest in Lithuanian culture, and then later she began participating in all the Bendruomenè activities and even taught Lithuanian culture to other non-Lithuanians. Another Bendruomenè member became interested in Lithuania because he was studying Lithuanian.

Traveling to Lithuania was another route by which nonLithuanians felt their identification with Lithuania was strengthened. An example of this is Mike, for example, was one of the non-Lithuanians who traveled with Aidas to Lithuania in 1992. His positive experiences there furthered his interest in Lithuania and Lithuanians. Since then, he has sent back gifts and money to the family he stayed with, and invited Lithuanians to visit the United States. His involvement has been so intense that there was even a short article published about him in the Kansas City Star entitled "The King of Lithuania." The article did not 
Ethnic Studies Review, Vol. 19, No. 1

mention he was not of Lithuanian descent, and the reaction of the LOA members was mainly one of pride that his involvement with Lithuania had been written about in the newspaper. He returned to Lithuania the summer of 1995 to visit with his "adopted" family.

Like the respondents of Lithuanian ancestry, many ethnic converts felt that their adopted identity was strengthened by their travel to Lithuania. Kevin Parker wrote that he identified more strongly with his adopted homeland, and that he understood Lithuanian pride better after his trip. He felt that the increased knowledge he had of Lithuania and Lithuanians gave him a stronger Lithuanian-American identity. Similarly, Sandy Bernatonis wrote that her visit to Lithuania "has made me even prouder to be Lithuanian when I see how they cherish their values." Darrell Kelley was even more deeply affected by his journey:

\begin{abstract}
After being there, I believe that Lithuania has something valuable to share with the world; how to tackle conflict non-violently and triumph of spirit over adversity. Although certainly not the first [country] in the world to do this, it is the first for me to be so intimately tied to.
\end{abstract}

For some of the respondents, their trip to Lithuania made them want to become more involved in Lithuanian-American activities and with efforts to help Lithuanians:

Darrell wrote that he wanted to be more active if he had time because, "the people in Lithuania need people in [the] U.S. to recognize their culture as unique and any participation helps this end."

Constance Samalavičius wrote about how her trip changed her perception of Lithuanian-American activities:

My role has been building over the last 10 years, I expect it to keep doing so. I hope to be more active with National and International progress for the needs of Lithuania.

Lisa Smith had similar goals as she wrote: "I would like to go and give my help or talents to rebuild and help fix, that which need[s] fixing." Mike Anderson wanted to extend his activities into Lithuania itself after his visit there: "I would live there for some time if there were something I could do to help Lithuania and its people."

Lithuanian independence strengthened the converts' identification with Lithuania, much as it did for people of Lithuanian descent. Kevin Parker wrote that Lithuanian independence gave him "even more reason for having pride in Lithuanian identity [and that] ... the personal 
experience and first hand stories about their fight made [him] even more proud." The combination of involvement with Lithuanian-American communities, travel to Lithuania, and the emotional impact of Lithuanian independence all served to create and reinforce a Lithuanian-American ethnic identity.

\section{Conclusion}

As can be seen from the above discussion, the acceptance or nonacceptance of non-Lithuanians can be an important part of how Lithuanian-American groups define themselves. Is it enough to simply "feel" Lithuanian, or must there be something else as well? Is participating in folk culture enough, or must one learn the language as well? Or, can one only be "Lithuanian" if one has Lithuanian "blood" or takes place in a naming ritual? Through participant observation and analysis of questionnaires, I have been able to see the important roles that nonLithuanians play in the LOA and Bendruomene. Usually the nonLithuanians are connected by marriage, but sometimes their only connection is an interest in Lithuanian culture and/or the needs of Lithuanians in Lithuania. These are just a few examples of the ethnic converts I have met and who shared their experiences with me. What is it that makes these people so eager to embrace the Lithuanian cause? As stated above, there were two main reasons for this; family and formal organizations. Women particularly often believe it is important to pass on an ethnic heritage to their children. If ethnic identity has not been maintained in one's own family, it is easy to be drawn into a spouse's (or other significant other's) ethnic identity.

A comparison of the LOA and Bendruomene reveals that the LOA has a greater tolerance for non-Lithuanians and indeed to ethnic Lithuanian Americans. The refugee experience perhaps plays a role in the different ethnic boundaries of the two groups. For the Bendruomene émigrés, it is important to be 100 percent Lithuanian and to maintain the language and culture for the inevitable return to Lithuania. For LithuanianAmerican ethnics of both groups and for younger émigrés, however, the definition for who is and who is not Lithuanian is looser. Both communities are adapting to changes in group composition through the years as well as grappling with the reality of a free Lithuania.

The efforts to maintain and construct Lithuanian-American identities through family structures and kinwork help decipher the puzzle of why ethnic identity remains salient even after generations in America. In addition, the study of ethnic conversions through formal organizations emphasizes the constructed nature of ethnic identity. Although the Lithuanians in Kansas City and Seattle no longer live in urban villages, they still consider themselves Lithuanian Americans and form a community despite the lack of ongoing daily interaction with fellow Americans of 
Ethnic Studies Review, Vol. 19, No. 1

Lithuanian descent. In the absence of such interaction, they must find new ways to maintain and create their ethnic identity. Among those ways are accepting and even encouraging non-Lithuanians to be full participants in Lithuanian-American communities.

This article reveals the important role of Lithuanian-American identity construction and its role in Lithuanian ethnic renewal. The LOA is able to expand its small size by accepting non-Lithuanians at all levels of the organizational structure. By embracing all those who feel Lithuanian, the LOA has been successful in maintaining a Lithuanian-American presence in the Kansas City area. Although Bendruomene has not been quite as tolerant of non-Lithuanians or even ethnic Lithuanian Americans, their ethnic boundaries are becoming more permeable as they realize that the small size of the Lithuanian-American émigré population in Seattle limits their activities. It is quite possible that, had the two groups adopted more rigid ethnic boundaries, they would have found it impossible to sustain Lithuanian-American communities in either Seattle or Kansas City.

\section{Notes}

1 This article was sent out for an external blind review by Ethnic Studies Reviewsenior editor, Miguel A. Carranza. The author would like to thank the reviewers, Miguel Carranza, and Joane Nagel for their insightful comments and suggestions.

2 Joane Nagel, American Indian Ethnic Renewal (Oxford, England: Oxford University Press, 1996); Sarah Deutsch, "Gender, labor history, and Chicano/a ethnic identity," Frontiers 14, 2 (1994):1-22; George J. Sanchez, Becoming Mexican American: Ethnicity, Culture and Identity in Chicano Los Angeles, 1900-1945 (New York: Oxford University Press, 1993); Julie E. Sprott, "Symbolic ethnicity" and Alaskan Natives of mixed ancestry living in Anchorage: Enduring group or a sign of impending assimilation?" Human Organization 53, 4 (1994): 311-323; Kerby A. Miller, Emigrants and Exiles: Ireland and the Irish Exodus to North America (New York: Oxford University Press, 1985); Anny P. Bakalian, Armenian-Americans (New Brunswick, NJ: Transaction Books, 1993); John Patrick Roche, "Social factors affecting cultural, national and religious ethnicity: A study of suburban Italian-Americans," Ethnic Groups 6 (1984): 27-45; Mary Patrice Erdmans, "Immigrants and ethnics: Conflict and identity in Chicago Polonia," Sociological Quarterly 36, 1 (1995): 175-195.

3 Eleanor Palo Stoller, "Sauna, Sisu and Sibelius: Ethnic Identity Among Finnish Americans." Sociological Quarterly 37, 1 (1996): 145-175.

4 Richard D. Alba, "The twilight of ethnicity among American Catholics of European ancestry," The Annals of the American Academy of Political 
and Social Science 454 (1981); Olivia Cadaval, "Making a place home: The Latino Festival," in Creative Ethnicity: Symbols and Strategies of Contemporary Ethnic Life, eds. Stephen Stern and John Allan Cicala (Logan, UT: Utah State University Press, 1991), 204-22; Larry Danielson, "St. Lucia in Lindsborg, Kansas," in Stephen Stern and John Allan Cicala, 187-203.

5 Cookie White Stephan, "Ethnic identity among mixed-heritage people in Hawaii," Symbolic Interaction 14, 3 (1991): 261-277; Fredrik Barth, Ethnic Groups and Boundaries (Boston: Little, Brown, 1969); Joane Nagel, "Constructing ethnicity: Creating and recreating ethnic identity and culture," Social Problems 41, 1 (1994): 152-176; Crawford Young, The Politics of Cultural Pluralism (Madison: University of Wisconsin Press, 1976); Mary C. Waters, Ethnic Options: Choosing Identities in America (Berkeley: University of California Press, 1990); Francois Nielsen, "Toward a theory of ethnic solidarity in modern societies," American Sociological Review 50 (1985): 133-149; Felix Padilla, "Latino Ethnicity in the City of Chicago," in Competitive Ethnic Relations, eds. Susan Olzak and Joane Nagel (Orlando, FL: Academic Press, 1986), 153-71; Eugene E. Roosens, Creating Ethnicity: The Process of Ethnogenesis (Newbury Park, CA: Sage Publications, 1989); Joane Weibel-Orlando, Indian Country, LA (Champaign: University of Illinois Press, 1991).

6 Stephan.

7 Weibel-Orlando.

8 Danielle Juteau, "The production of ethnicity." Paper presented at the meeting of the American Sociological Association, Cincinnati, OH. August, 1991.

9 Sarah Deutsch, No Separate Refuge: Culture, Class, and Gender on an Anglo-Hispanic Frontier in the American Southwest, 1880-1940 (New York: Oxford University Press, 1987).

${ }^{10}$ Susan Kellogg, "Exploring diversity in middle-class families," Social Science History 14 (1990): 27-42.

${ }^{11}$ The Lithuanian Scouts Association, Inc. is comprised of scouts of Lithuanian descent from all over the world. It is primarily a diaspora organization. The association was developed both to follow "the scouting ideals of Lord Robert Baden-Powell" and to create opportunities for girls and boys of Lithuanian descent to meet and eventually "perpetuate scout families"; Antanas J. Van Reenan, Lithuanian Diaspora: Königsberg to Chicago (Lanham, MD: University Press of America, 1990). 
12Micaela di Leonardo, The Varieties of Ethnic Experience (New York: Cornell University Press, 1984).

13 Micaela di Leonardo, "The female world of cards and holidays," Signs: Journal of Women in Culture and Society 12 (1987): 440-453.

${ }^{14}$ Obviously, ethnic conversions are quite different from religious conversions in terms of the centrality of an ethnic versus a religious identity. In addition, ethnic identity is more clearly rooted in ancestry, whereas religious identities are more likely to be viewed as matters of belief. Therefore, respondents are unlikely to write that they are Lithuanian, but rather that they identify with Lithuania and Lithuanians. One respondent did, however, write that she was Lithuanian, despite being of Irish ancestry.

${ }^{15}$ Arthur Greil and David R. Rudy, "Conversion to the world view of Alcoholics Anonymous: A refinement of conversion theory," Qualitative Sociology 6 (1983): 5-28.

16 David A. Snow and Richard Machalek, "The convert as a social type," Sociological Theory (1983): 259-289; Snow and Machalek, "The sociology of conversion," Annual Review of Sociology 10 (1984): 167-90.

${ }^{17}$ Mark C. Suchman, "Analyzing the determinants of everyday conversion," Sociological Analysis 53 (Supp, 1992): S15-S33.

18 Lynn Davidman and Arthur L. Greil, "Gender and the experience of conversion: The case of 'returnees' to modern Orthodox Judaism," Sociology of Religion 54, 1 (1993): 83-100.

${ }^{19}$ Stephan.

${ }^{20}$ Michael Yellowbird and C. Matthew Snipp, "American Indian families," in Minority Families in the United States, ed. Ronald L. Taylor (Englewood Cliffs, NJ: Prentice Hall, 1994), 179-201, 187.

${ }^{21}$ Arthur Greil and David R. Rudy, "What have we learned from process models of conversion? An examination of ten case studies," Sociological Focus 17, 4 (1984): 305-23, 318.

${ }^{22}$ Greil and Rudy, 1984.

${ }^{23}$ Stephan. 
24I define ethnic converts as individuals who are highly involved in an ethnic community with which they have no biological connection. By "highly involved," I refer to people who do more than attend ethnic functions with friends or family members. That does not necessarily mean that they renounce their own ethnic ancestry, simply that they are more involved with ethnic groups other than their own.

${ }^{25}$ Although more men than women are labeled as ethnic converts in my study, the women tend to be more active than even their (usually Lithuanian-American) husbands. The men, on the other hand, are not as active in their Lithuanian-American ethnic identification but are simply swept along with their in-laws' ethnic activities.

26 In fact, it might be possible that all four officers are non-Lithuanians. The vice president knows he is of Prussian descent, and assumes he may have some Lithuanian ancestry, but he does not really know. (Prussia was one of the powers that divided the Lithuanian-Polish Commonwealth. Most of Lithuania came under czarist Russian control, but "Lithuania Minor" was under Prussian rule.)

27 Varpas, October 1981.

${ }^{28}$ Barth.

${ }^{29}$ Barth.

30 Interview with Loretta Lopez conducted by Natalie Werner, Seattle, Washington, 1992.

31 Interview with Gintas Nalis conducted by Natalie Werner, Seattle, Washington, 1992.

32 Interview with Irena Blekys conducted by Natalie Werner, Seattle, Washington, 1992, when Irena was the president of the Seattle chapter of Bendruomenè.

${ }^{33}$ Tulpé Times, August 1986, p. 3

${ }^{34}$ Scott Hampton.

35Nagel, 1996.

36Hannah Kubacheck. 
Ethnic Studies Review, Vol. 19, No. 1

${ }^{37}$ Davidman and Greil.

38M. Herbert Danzger, Returning to Tradition: The Contemporary Revival of Orthodox Judaism (New Haven, CT: Yale University Press, 1989).

39Interview with Wayne Karpisek, February 26, 1994. 